\title{
ECOS DE HISTORIA ROMÁNTICA: LA «ESPAÑA MORA» EN THOMAS RODD Y WASHINGTON IRVING
}

\author{
Por \\ OVIDIO CARBONELL CORTÉS
}

Cuando los románticos ingleses que visitaron España decidieron dar forma literaria a aquel mundo tan esplendorosamente evocador, tan adecuado a su nueva sensibilidad, que habian descubierto en las abigarradas costumbres de sus gentes, en los montes y en las ciudades abandonadas tanto como en la vida de sus calles y plazas, recrearon un particular y «pintoresco» universo de ensueño, muy idealizado, en el que poder refugiar su deseo de huida y cristalizarlo en relatos de pasiones y de odios en el escenario del pasado gótico o árabe hispánico, o del presente todavía oscuro y cargado de tradición. Imágenes por descontado estereotipadas y excesivamente subjetivas, pero cuyo especial concepto de lo bello y lo sublime llega en ocasiones a sobrecogernos también a nosotros.

Dentro de la visión romántica de España, no puede pasarse por alto la imagen de su pasado árabe, que para el romántico inglés sigue vivo no sólo en los restos arqueológicos, sino en la misma vida cotidiana del español decimonónico. Una identificación que muchos ingleses de hoy en día siguen evocando cuando se les menciona el nombre de España, tanta fuerza tuvo como inyección exótica en el arte y la vida del romanticismo inglés. Es una visión subjetiva e imaginativa, un cúmulo de tópicos propios, que sirvieron empero como una manera de acercarse a la realidad española a pesar de su efecto deformante, de ver precisamente lo que ellos querían ver, de cambiar sus monóculos por el cristal verde de la imaginación romántica y filtrar a través de ellos las gentes, los pueblos, las catedrales góticas y los palacios árabes. Por ello siempre he preferido en este sentido la denominación de «España mora», y no árabe o islámica; ni siquiera al-Andalus, pues no era esto lo que Southey. Irving, Lord y Lady Holland, o el mismo Byron veían y recreaban al descubrir el pasado árabe de España - Moorish Spain-, sino su propio universo amalgama de elementos góticos y orientales, de valores cabalierescos y belleza difusa. Un escenario que nos es familiar, pero que no nos pertenece. 
En el conjunto de las obras románticas inglesas y norteamericanas que trataron el tema de la España oriental hallamos tanto poesía como prosa y teatro. La lírica es la cima de la individualista sensibilidad romántica, y así algunos de los más afamados literatos de la época compusieron poemas cantando tal o cual leyenda, o dejando volar la imaginación por el escenario oriental, o simplemente tradujeron alguno de los romances moriscos que tan de moda se pusieron en Inglaterra desde finales del XVIII. Pero lo que verdaderamente popularizó el tema fue el conjunto de obras en prosa que proliferó tras las visitas de los viajeros «románticos»: relatos de viajes -en los que no faltaban aventuradas traducciones de romances- y también traducciones de obras historiográficas hispánicas, así como estudios históricos, referidos especialmente al período árabe o gótico español. La historia siempre está presente en el ánimo romántico; su espíritu nostálgico en busca de épocas y lugares mejores le lleva a volver la cabeza al Mediodía, al que cree último refugio del esplendor y los valores humanos que admira de su idealizada Edad Media.

$\gamma$ el público inglés -y norteamericano- «readers at home», leyó ávidamente desde su casa los relatos de estos lugares lejanos en el espacio, en el tiempo, o ambos, y, popularizándolos, contribuyó a una creciente cadena de peregrinos y al consecuente volumen de obras repletas del romántico color local hispano-gótico-oriental. Entre toda esta explosión creativa queremos destacar dos figuras excepcionales por su importancia como punto de partida para otras obras: la traducción al inglés de las Guerras Civiles de Granada, de Pérez de Hita, por Thomas Rodd (1801), y A Chronicle of the Conquest of Granada from a Ms by Fray Antonio Agapida por Washington Irving (1829). Dos obras historiográficas que narran hechos dramáticos del fin de la dominación musulmana; traducción en un caso, ficción histórica en el otro, y que de todos modos reflejan la actitud general romántica hacia el mundo hispano-árabe.

\section{Thomas Rodd}

Thomas Rodd, hijo de un comerciante acomodado con negocios entre Londres y Alicante, vivió durante tres años en esta ciudad, que quizás despertara en él su entusiasmo por España, sus costumbres y su pasado. Él es el responsable de la difusión de la obra de Hita y su particular clima «maurófilo», así como el primero que llevó a cabo una traducción extensiva de romances procedentes de las Guerras Civiles (1), tras las pioneras de Percy y Pinkerton. Su mayor obra incluye un prefacio en el que alterna alguna nota costumbrista (es destacable su viva descripción de las fiestas de moros y cristianos de Alicante, como nota marginal (2)) con observaciones

(1) THOMAS RODD: Ancient Ballads from the Civil Wars of Granada, London, 1803

(2) Esta descripción viene dada en el capitulo X, p. 124, como nota a la narración de las fiestas de San Juan en la novela de Hita, tras el combate entre Alabez y Ponce de León. La fantástica majestuosidad de sus desfiles le hace introducir esta nota en la que les da credibilidad, justificándose en la experiencia de sus viajes. Pone por ejemplo las fiestas de moros y cristianos de Alicante -que traducimos a continuación- asi como la Procesión del Primus de Lovaina en Brujas (1782).

«Quizás, si fuera más lejos y dijera que doy crédito a estas ficciones, sería considerado demasiado fantasioso; contaré simplemente que, al llegar a España poco después de la paz de 1783, fui testigo de las fiestas que con tal motivo se celebraron. Una invasión simulada de los moros constituia la parte principal de ellas. Por la mañana temprano del día señalado la escuadra mora fue descubierta en la bahia de Alicante, se dio la alarma, pero los moros pudieron desembarcar y, al tomar posesión de una bateria, la ciudad capituló. Por la tarde, los cristianos se rehicieron y asaltaron la fortaleza, pero fueron rechazados. Entonces la guarnición 
sobre la civilización árabe andalusí. Reconoce así la grandeza hispanoárabe frente a la oscuridad y barbarie europea, un punto de vista bastante nuevo:

This city [Cordova] was considerable even in the time of the Romans, and being enlarged and embellished by the Caliphate governors, and during the reign of Abdulrahmen and his successors, became eminent in arts and arms, in magnificence and learning, and was justly esteemed the most splendid city in Europe; and what renders it the more deserving of notice, is, that the rest of Europe was immersed in barbarity at this period, which, in our days, is distinguished by the disgraceful appellation of the dark age (3).

Tras una breve relación de acontecimientos políticos andalusies, reconoce también la grandeza romántica del período que llevó a la conquista de Granada por los Reyes Católicos, «a period of Spanish glory» (4)

En cuanto a la autenticidad de la obra, cree en la existencia de un original árabe que habría de buscarse en los archivos de la familia Ponce de León, descendientes según él de los duques de Arcos. Admite que Ginés introdujera interpolaciones, que cree se basan en su parcialidad a los cristianos, mientras que la exactitud de las descripciones revelarian su origen árabe (5). Contrariamente a Irving, por ejemplo, que siempre mantuvo cierta distancia entre la realidad y la fantasía, la imaginación romántica de Rodd le hizo creer en los fastuosos y sentimentales episodios de Hita (6).

Por lo que respecta a la traducción en sí, Rodd sigue más o menos fielmente el estilo sencillo y claro de Hita, añadiendo algunas notas explicativas, y modificando algunos romances, en los que realiza interpolaciones, o versifica párrafos en prosa En algunas de estas ocasiones en las que Rodd se aleja del original del autor mur. ciano, apreciamos que se tiende a modificar el estilo renacentista, y a introducir un color local más apropiado al entorno romántico. Es entonces cuando Rodd añade a la «maurofilia» morisca su propia recreación, trocando en entorno paradisiaco los

mora hizo una salida, y los dos escuadrones de moros y cristianos se encontraron en la Plaza Mayor, que por lo general significa la plaza principal, pero que aqui se podría traducir más propiamente por la plaza más amplia de la ciudad. Siguió una feroz batalla, que acabo al cortarle el caudillo cristiano la falsa cabeza al general moro. El lector puede discernir mediante esta anécdota que España no ha olvidado el resentimien. to de la invasión mora. La batalla no estuvo de ningún modo exenta de magnificencia, pues los trajes de los moros y cristianos correspondian perfectamente a los de estas diferentes naciones.

(3) Las Guerras Civiles, or The Civil Wars of Granada, and the History of the Factions of the Zegries and Abencerrages, two Noble Families of that City, to the final Conquest by Ferdinand and /sabella. Transiated from the Arabic of Abenhamin, a native of Granada, by Ginés Pérez de Hita, of Murcia; and from the Spanish by Thomas Rodd. London, J. Bonsor, Salisbury Square, 1801. Prefacio, pp. VI-VII.

(4) Ibid., p. Vili.

(5) Vid. nuestro estudio La Esoaña mora en la literatura romántica inglesa. Memoria de Licenciatura, Facultad de Filosofía y Letras, Alicante, 1989, pp. 109-110. La creencia en un precedente árabe original de los romances tanto como de las obras moriscas en prosa era creencia general entre los europeos románticos. Tan sólo algunos, como Percy o lrving, mencionan sus dudas al respecto.

(6) Ibid., p. XI. «lf the Arabian manuscript could now be found, by searching the Archives of the Ponce de León family, from whom, I believe, the dukes of Arcos are descended, it would establish the fact beyond dispute, which at present is involved in some difficulty; however, i cannot entertain the slightest doubt that Ginés Pérez had an original manuscript before him, from which he translated the first volume of his Las Guerras Civiles. at the same time, that I am ready to admit, he has introduced many interpolations of his own; a partiality to the Christians prevaits through the whole book, and there certainly are some passages which a Moor could not have wrote. But on the other hand, the accurate knowledge of the Moorish tribes and lineages settled in Granada, before the conquest of the city by the monarchs of Castile, could, I think, only be known to a contemporary (sic) Moor, and not to another, who wrote at a distance of a century after the period of the history, and pretty clearly establishes the work to be of Moorish origin?. 


\section{LAS \\ GUERRAS CIVILES;}

OR THI

CIVIL WARS OF GRANADA;

AND

THE HISTORY

oy $\mathrm{TaE}$

FACTIONS OF THE ZEGRIBS AND ABENGRRRAGES,

TWO DYOBL TAYLLIE OP THAT CITY.

TO THE

FINAL CONQUEST

ax

FERPINAND AND ISABELLA.

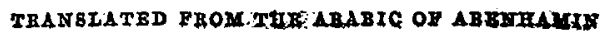

4 ratrive of Orartad,

BY GINES PEREZ DE HITA, OF MURCLA

AND FRONTHE SPANISH

BY THOMAS RODD.

rot 1

LONDON.
Priated by J. Bonfot, Sathipury Squave;

POR TAF AUTHOR.

AND SOLD ET VERWOK AND GOOD, POULTRY; MUEX.

QUEEN BTKEIT; AMD CHARTHB, RALL-MALL.

1801. 
detalles circunstanciales del original, tan propios de la novela caballeresca del dieciséis. A modo de ejemplo, hemos escogido uno de estos párrafos, que puede encontrarse en la página 293 de la edición inglesa, correspondiente al final del capítulo XIV. En él, un fragmento descriptivo henchido de pintoresca belleza andaluza, el traductor inglés aprovecha para introducir una consideración personal sobre el mito de al-Andalus perdido - verdadero Paradise Lost - de la antigua dominación musulmana y su extinción, que se materializa en una nueva «ballad» o romance muy probablemente de su propia factura:

[The knights] ...entered the beautiful campaign of the Vega, and rode gently onward towards the city, admiring on all sides the beautiful views, the diversity of the streams meandering through their varied courses, the gardens, vineyards, and orchards, futl of trees, and bending with the choicest fruits to the ground, which made the country appear to them like an earthly paradise: and let not the reader marvel at the beauties of nature which presented themselves to the Cavaliers, for no bed of carnations, or of the sweetest scented herbs, was ever more highly cultivated than every spot of ground, whether it was situated far off or near the city, or whether it was hill or valley, by the Moors, and which is at this a barren waste.

En esta interpolación Thomas Rodd se acerca quizás a la intención apologética de Pérez de Hita en revalorizar la figura islámica frente a la intolerancia real. Posiblemente no podría haber encontrado nuestro traductor un episodio más apropiado en el cual introducir su cántico a la perdida Edad de Oro hispanoárabe; los caballeros cristianos, vestidos de turcos, se apresuran a la corte granadina a defender en una justa, así disfrazados, el honor de la reina mora puesto en entredicho. Todo un ejemplo de ideal caballerosidad que choca de frente con el moro solitario recreado por Rodd, que a las orillas del Darro entona un romance «lamenting the unfortunate change», una elegía a los moriscos expulsados:

Christians, that in war long practis'd,

Every peaceful thought forego,

Christians, that in blood delighting,

Taught Granada's tears to flow.

(vv. 56-60, p. 296)

En el prefacio a la obra. Thomas Rodd reprocha algunos defectos de las traducciones de Pikerton a la vez que alaba las de Percy, «so beautifully rendered». Cuenta que halló las versiones de Pinkerton en el último momento, sorprendiéndose de sus imperfecciones, su falta de musicalidad y desorden, concluyendo que:

from the mistranslations in the first of the ballads, I conceive the person who attempted the translation had a very imperfect knowledge of the Spanish language, and in the last he speaks of the Alpujarra wall, mistaking the mountains for a city (7).

Diriase que el debate a principios del XIX, a partir de las opiniones de unos y otros traductores (8), se centraba en la belleza de la forma inglesa más que en la fidelidad al original, que goza de un amplio margen de libertad siempre y cuando no se sobrepasen ciertos límites. Ciertamente, el mismo Rodd se tomó sus buenas liber-

(7) Ibid., pp. XIV-XV. Sobre Percy, vid. A.W. Jones, "A Pioneer Hispanist: Thomas Percy", Bulletin of Hispanic Studies, XIV, 1937, pp. 3-9. Sus traducciones, a las que hacemos referencia, aparecen en sus Reliquies of Ancient English Poetry, vol. I, London, 1765, pp. 335-347.

(8) Sobre las traducciones del romancero, vid. O. Carbonell, op. cit., pp. 105-129. 
tades en varias de las «ballads» que incluye la obra de Hita, versificando algunos párrafos que en el original están en prosa (9), o incluso inventándose algunas. E. Buceta, infatigable investigador de las traducciones inglesas del romancero, anotó en un extenso estudio sus sospechas acerca de la posible imitación de los romances que van del n. ${ }^{\circ}$ XLIX al LI; ciertamente he encontrado romances que no existen en el original, pero sus números no se corresponden con los señalados por Buceta, y, de hecho, la traducción de Rodd recoge tan sólo 34 romances. Por ejemplo, el breve romance que aparece en quinto lugar tiene un extraño añadido, que no se encuentra en el original. Recrea la batalla entre Muza y el Maestre de Calatrava (10), descrita en prosa en páginas anteriores. Otro romance merece una atención más detenida, se trata del lamento morisco al que antes aludíamos. Como allí comentábamos, forma parte de un inciso del propio Rodd, que presenta la nueva «ballad» dejando explicita su procedencia: «Our English translator presents the reader with the picture of a Moor...", del mismo modo que en el quinto romance, en el que señala: "The Translator here also begs leave to introduce a ballad on the late battle, which he hopes will not lessen the merit of the work».

Rodd conocía la historia de los moriscos, que habia leído en los «Tracts of the learned Dr. Geddes, the Chancellor of Sarum, Vol. l», y era, pues, consciente de la fabulosa índole de la «morofilia» del dieciséis. Su «romance», una representativa reflexión romántica sobre el paso del tiempo, no posee una calidad literaria de ningún modo excepcional, repite muchos tópicos e incluso construcciones ya existentes en las traducciones de Percy: «Softly flow...», por «Softly blow...», gerundios y adverbios al principio de verso, etc. De todos modos transcribimos el romance, por tratarse de una imagen algo distinta, más dramática en el sentido romántico, en el conjunto de la obra; por su brevedad, y por ser esta versión inglesa indudablemente difícil de hallar: el canto de uno más entre tantos peregrinos románticos ingleses que pisaron nuestra tierra e identificaron con ella, con sus gentes y con su pasado legendario, sus más profundos sentimientos:

Softly flow thou pleasant river, Stream that every Moor reveres;

Let thy murmurs sooth my sorrows, Whilst I swell thee with my tears

For Granada am I weeping, For Granada far renown'd;

Lo! her choicest sons lie slaughter'd, And her streets in blood are drown'd!

All her tow'rs and fairest cities By the Moors esteem'd high,

Strong built forts and lofty castles Now in scatter'd ruins lie.

All her flow'ry fields and gardens, Gardens form'd with matchless taste,

(9) E. BUCETA: “Traducciones inglesas de romances», Revue Hispanique, LXII, 1924, p. 465. Se trata de las "ballads" que tienen por nos. XVIII y XIX.

(10) TH. RODD, op. cit, (1801), p. 45. 
Where the pendent fruit hung shining, Now remain a desert waste.

Mosques so pure, and stately mansions, Seem dissolv'd in clouds of smoke;

Pleasant woods and lofty pine-trees Bow beneath the axe's stroke.

Where the joyful sports were acted Stalks the meagre fiend despair, Where the softest music sounded Shrieks of horror rend the air.

For her spouse the frantic widow Tears her hair and beats her breast, At her cruel fate exclaiming, With distracting thoughts oppres'd.

And the tender piteous orphan, In each hopeful pleasure cross'd, Clinging round its helpless mother, Mourns a fire untimely lost.

Chang'd with grief, the lovely damșel Tells the empty wind her pain, And her hands in anguish wringing Weeps a faithful lover slain.

Red like blood the sun appearing Sheds a sanguinary gloom, And convulsive nature trembling Seems to wait a final doom.

Softly flow...

No more on thy verdant borders Shall the tender lovers stray,

And in sweet enchanting converse Pass the happy hours away.

No more shall the bark so smoothly Float along thy trembling wave, Nor the youths with heat all weary In thy crystal current lave.

On thy banks where op'ning flow'rets Spread their beauties to the day, Oft at night the Moor shall wander, To the Christian doom'd a prey.

Christians, that in war long practis'd, Every peaceful thought forego, Christians, that in blood delighting, Taught Granada's tears to flow.

Softly flow thou pleasant river... (11).

(11) lbid., pp. 294-296. 


\section{Washington Irving}

La novela de Pérez de Hita parece haber sido uno de los primeros libros españoles que Irving conociera en su juventud (12). Williams cita un testimonio del propio Irving acerca de sus lecturas de la conquista de Granada

From earliest boyhood, when, on the banks of the Hudson, I first pored over the pages of old Gines Perez de Hyta's apocryphal but chivalresque history of the civil wars in Granada, and the feuds of its gallant cavaliers, the Zegries and the Abencerrages, that city has ever been a subject of muy waking dreams; and often have I trod in fancy the romantic halls of the Alhambra (13).

Para su «The Student of Salamanca», primera obra de ambiente granadino, recogida en Bracebridge Hall, utilizó la traducción de Rodd, pero es un hecho comprobado que la versión original fue uno de sus libros de lectura, junto con Cervantes, cuando empezó a estudiar la lengua castellana. Su creciente interés por Granada y su historia no produjo solamente las mundialmente conocidas The Alhambra. A Series of Tales and Sketches of the Moors and Spaniards (1832), sino también una monumental obra histórica, tres años anterior, e inspirada tanto por Hita como por la ingente documentación que pudo consultar el escritor americano. Obra esta, junto con el resto de las de Washington Irving, representativa de la segunda corriente «maurófila» del romanticismo europeo-norteamericano, que se opone a la casi puramente «goticista» de la primera década del XIX. Aquélla revaloriza el mundo y el arte oriental, que en Southey, por ejemplo, sólo puede entreverse como un fondo difuminado que matiza con un sabor adicional el plano principal gótico. Tal búsqueda de lo oriental queda muchas veces matizada en la recreación de la España musulmana mediante un rasgo esencial: la unión de características propias de lo gótico - del lado cristiano-, y de lo oriental - del lado «moro»-. Combinación que hallamos en la descripción de los escenarios y, sobre todo, en la conducta de los personajes, que en algunos autores parecen compartir las características encumbradas a las que antes haciamos mención (14).

Un modelo de historicismo «maurófilo» de los escritores que hemos consultado es, pues, la no tan conocida obra de Irving, A Chronicle of the Conquest of Granada. Intentemos dilucidar qué es esta obra en realidad, si historia, ficción o ambas; y qué calidad literaria puede atribuírsele. La obra, en sí, es historia novelada. Irving era un apasionado de la historia, como tantos otros románticos, que suplió en la española la falta de un auténtico pasado medieval en su país. Así cuenta que pasó muchas tardes entre los libros de la biblioteca de los Padres Jesuitas, en un principio recopilando documentación para su Historia de la vida y viajes de Colón (1833-34). Entre esa documentación, trabó conocimiento con la multitud de crónicas hispánicas de la época, que le entusiasmaron sobremanera. Se dice que Irving no pudo acabar su «vida de Colón» hasta haber llevado a cabo la redacción de una obra histórica sobre el tema de la conquista de Granada, tan absorbido se vio por él.

(12) WILLIAMS, STANLEY THOMAS: The Spanish Background of American Literature, 2 vols. New Haven/New York, 1955, II, p. 9; también en Andrés Soria, «Washington Irving, 1859-1959. Notas en su centenario», en v. aa. Washington /rving, Universidad de Granada, 1960, pp. 121-159.

(13) WASHINGTON IRVING: The A/hambra..., 1832

(14) Sobre este aspecto híbrido de la consideración romántica de la historia, véase al respecto 0 . Carbonell, op cit., parte II, cap. 2, «El arte árabe como fuente de inspiración del romántico», pp. 57-69. 
La crítica actual contempla este grueso volumen con buenos ojos, reconociendo calidad literaria a los pasajes ficticios, así como su rigor histórico en general (15), mientras que en su época no se apreció el valor del libro como se debiera, aunque fuese popular, y la polémica sobre la fidelidad de sus fuentes llegó hasta el presente siglo. En realidad, Irving tomó de aquí y allá episodios de diversas fuentes y los hilvanó en una única trama argumental que, si bien resulta repetitiva, tiene fuerza descriptiva y es bastante equilibrada. Se ha reprochado a lrving que extrajera de su imaginación el personaje de Fray Antonio Agapida, el fautor, compilador ficticio, que le abre la posibilidad de recrear algunos episodios. Pero si en algún momento se aleja de la historia real, su libro gana en riqueza artística y, al comentar el supuesto escrito de Fray Antonio Agapida, se permite el adoptar también una postura más distante y crítica en ocasiones respecto al mundo de las crónicas medievales, sin dejar de imitar el estilo propio de éstas, de tanto sabor heroico y pintoresco. M. a Soledad Carrasco apunta que estos incidentes novelescos urdidos por Irving «prestan extraordinaria gracia al libro, si bien en estos casos da ciertas indicaciones que permiten al lector avisado discriminar entre lo que el autor consideraba rigurosa historia, y los devaneos de su fantasía» (16). Indicadores que, aparte de algún párrafo evidentemente romántico en el sentido más estereotipado del adjetivo, vienen dados por la útil mención de Fray Antonio Agapida en estilo indirecto.

Esta intromisión del fantástico cronista tiene dos motivos importantes. El primero, el deseo de imitar el estilo de las crónicas medievales mediante la introducción de comentarios u opiniones, muchas veces subjetivas, más propias de aquella época que de un historiador moderno del XIX. El segundo, que ello permite a Irving tratar a su falso cronista con su ironía característica, que se acerca en ocasiones a la parodia y a la sátira. Por medio de Agapida, Irving critica y se burla del fanatismo de los historiadores católicos de la época, al servicio de la razón de estado, del tipo de la Justa expulsión... (Fonseca, 1612), o las mismas obras que cita, muchas de la misma índole, que tratan el Islam y los nuevos conquistados con intolerancia reprobable. Este carácter crítico se repite en muchísimos pasajes a lo largo de toda la obra, como el siguiente:

«The old Moor stood on the lofty tower of the Alhambra» says Antonio Agapida, "grinding his teeth, and foaming like a tiger shut up in his cage, and the standard of the cross shining forth from amidst the smoke of infidel villages and hamlets. The most catholic king", continues Agapida, "would gladly have persevered in this righteous ravage, but his munition began to fails (17).

La opinión de Irving como narrador queda clara en la pág. 236. El conde de Tendilla ha estado instruyendo a los jóvenes en los ideales de la hidalguía. Con el fin de presentar a este caballero como héroe, Irving hace que Agapida lo describa,

(15) Vid. el artículo de Louise M. Hoffman, «lrving's Use of Spanish Source in The Conquest of Granada", Hispa nia, XXVIII (1945), pp. 483-498. Hoffman demuestra que Irving, aún en sus dramatizaciones, sigue con bas. tante exactitud fuentes historiográficas o romances referentes a los hechos. En la exposición la autora sigue las fuentes de Mármol, Hurtado de Mendoza, Pérez de Hita, y el romance de la muerte de Aliatar (una lisla completa de las fuentes mencionadas por Irving se encuentra en nuestro estudio citado, pp. 94-95). El articu lo es breve, pero esencial para la rehabilitación de la obra de Irving.

(16) CARRASCO URGOITI, M. a SOLEDAD: El moro de Granada en la literatura (s. XV-XX), Madrid, Revista de Occidente, 1956, p. 244

(17) WASHINGTON IRVING: Chronicle of the Conquest of Granada from a Ms by Fray Antonio Agapida. Lon don/Philadelphia, 1829, vol. I, pp. 179-80. 
imitando el estilo croniquesco, y criticando a su vez la intolerancia habitual de los cronistas:

But we cannot describe the character and conduct of this renowned commander in more forcible language than that of Fray Antonio Agapida, excepting, that the pious father places, in the foregroud of his virtues, his hatred of the Moors (18).

La imitación del estilo de las crónicas medievales hace que Irving incluya enumeraciones, datos biográficos de personajes, detalles minuciosos e irrelevantes como los relativos al protocolo, etc., usualmente siguiendo una acción «a saltos» propia de estas obras, utilizando comillas a principio de párrafo. Un buen ejemplo lo tenemos, por ejemplo, en las páginas 222 a 225. Incluso Irving «omite» deliberadamente «a long eulogy» de Agapida "on the scrupulous discrimination of the Castilian court» (p. 222). Es significativa la nota al final del capítulo:

The account given by Fray Antonio Agapida, of this ceremonial, so characteristic of the old Spanish court, agrees, in almost every particular, with an ancient manuscript, made up from the Chronicles of the Curate of Los Palacios, and other old Spanish writers (19).

Como historia novelada que es, hay una tendencia acusada a dramatizar los sucesos mediante diálogos de los personajes implicados, o de detalles que adquieren en ocasiones una personalidad decididamente romántica. Veamos la despedida de Boabdil de su esposa Morayma, al partir éste de algarada sobre Lucena:

His favourite wife Morayma wept, as she thought of the evils that might befall him. «Why dost thou weep, daughter of Ali Atar?» said the high-minded Ayxa; «These tears become not the daughter of a warrior, nor the wife of a king. Believe me, there lurks more danger for a monarch within the strong walls of a palace, than within the frail curtains of a tent. it is by perils in the field, that thy husband must purchase security on his throne».

But Morayma still hung upon his neck with tears and sad forebodings; and when he departed from the Alhambra, she betook herself to her mirador, which looks out over the Vega; whence she watched the army, as it passed in shining order along the road that leads to Loxa; and every burst of warlike melody that came swelling on the breeze was answered by a gush of sorrow (20).

No podemos dejar de apreciar que Irving ha utilizado los usuales tópicos de moras sentimentales a lo Chateaubriand, unidos a experiencias personales de la Alhambra, y a la tradición de Ayxa, la madre de Boabdil, como mujer de armas tomar y de no poca visión política.

En otras ocasiones, la dramatización se acerca mucho al tono ensoñador de sus próximas Tales of the Alhambra, como el momento en el que Cidi Caleb ha anuncia-

(18) Ibia., p. 236 (vol. l)

(19) Ibid., p. 224 (vol. I).

(20) Ibid., pp. 137-138 (vol. I). Parece que Irving está confundiendo a la esposa de Boabdil, que aparece en el Romancero con el nombre de Zara, con su hermana, que si se llama Morayma, tal y como aparece en las Guerras Civiles de Pérez de Hita. En el cap. 13 de esta obra, la madre y esposa de Boabdil miran efectivamente su partida, aludiéndose a esta última como la Reyna, sin nombre de pila. Noticias sobre esta Morayma, esposa de Abilhamad Abencerrage, aparecen sobre todo en el capitulo 14, pp. 225-227, del libro de Hita. en el que se narra su legendaria muerte junto con su hijo a manos de Boabdil. 
do la muerte de Ali Atar. El tono profético de la desesperación de los granadinos prefigura la nostalgia romántica por los palacios desolados:

The royal minstrels were summoned, to assuage the sorrows of the queen: they attuned their instruments to cheerful strains; but, in a little while, the anguish of their hearts prevailed, and turned their songs to lamentations.

«Beautiful Granada!» they exclaimed, «how is thy glory faded! The vivarrambla no longer echoes to the tramp of steed and sound of the trumpet; no longer is it crowded with thy youthful nobles, eager to display their prowess in the tourney and the festive tilt of reeds. Alas! the flower of thy chivalry lies low in a foreign land! The soft note of the lute is no longer heard in thy mournful streets, the lively castanet is silent upon thy hills, and the graceful dance of the zambra is no more seen beneath thy bowers! Behold, the Alhambra is forlorn and desolate! In vain do the orange and myrtle breathe their perfumes into its silken chambers; in vain does the nightingale sing within its groves; in vain are its marble halls refreshed by the sound of fountains and the gush of limpid rills! Alas! the countenance of the king no longer shines within those halls; the light of the Alhambra is set for ever!» (21).

Contemplemos ahora un paisaje particularmente representativo de la atmósfera medieval romántica que buscaban recrear todos estos escritores. Se sitúa en un paraje sugerente, la Roca de los Enamorados, The Lover's Rock, el mismo paraje en el que Southey situó su trágica pero graciosa «ballad» al estilo del romancero hispánico, basada en una leyenda recogida por el Padre Mariana. En la Chronicle de Irving tal escenario es el lugar del campamento del rey Fernando, donde se reúnen combatientes cristianos de varios países al lado de los españoles. Naturalmente, se enfatiza la presencia inglesa en torno al mítico English Earl, Lord Scales. En su atmósfera medieval, se recrea un ambiente de batalla idealizado, de alegre y caballeresca reunión plagada de los usuales clichés románticos sobre la idiosincrasia de los extranjeros. Notemos que las ancient ballads europeas - y sobre todo hispánicasson el vehículo por medio del cual se conjura esta atmósfera:

The mingled sounds of various tongues and nations were heard from the soldiery, as they watered their horses in the stream, or busied themselves round the fires which began to glow, here and there, in the twilight: the gay chanson of the Frenchman, singing of his amours on the pleasant banks of the Loire, or the sunny regions of the Garonne; the broad guttural tones of the German, chanting some doughty kriegerlied, or extolling the vintage of the Rhine; the wild romance of the Spaniard, reciting the achievements of the Cid, and many a famous passage of the Moorish wars; and the long and melancholy ditty of the Englishman, treating of some feudal hero or redoubtable outlaw of his distant island (22).

La leyenda de la muerte de otro personaje mítico, Don Alonso de Aguilar (tercer apéndice de la Chronicle of the Conquest of Granada) ofrece a Washington Irving la ocasión para recrear la rebelión de las Alpujarras. Tal caballero, distinguido en la

(21) Ibid., p. 168 (vol. l). Aunque no 10 menciona en sus profusas notas, Felicia Dorothea Hemans nos sorprende con un pasaje excepcionalmente similar en su The Abencerrage, escrito 10 años después (1839) que la obra de Irving fuera editada simultáneamente en Londres y en Filadelfia. ¿Leyó Hemans la obra de Irving o, simplemente, es fruto de la casualidad, de la similitud de la imagen romántica de Granada y España, que afloren tópicos parecidos en una escena que trata el mismo tema, el contraste del pasado y el presente? El pasaje puede verse en $\mathrm{O}$. Carbonell, op. cit., p. 217

(22) Ibid., vol. I, p. 34.4 
toma de Granada, y artífice de la muerte del famoso Aliatar, muere a manos del rebelde El Feri, en un episodio que sigue la línea del resto del libro. Irving, que suele equilibrar su prosa tratando de ser lo más objetivo posible, trata el tema morisco con cierta distancia, sin juzgar los hechos, aún habiéndose basado en fuentes cristianas justificativas de la política oficial, como la del Padre Bleda o Abarca. De este modo, en la dramatización de los hechos, dignifica Irving tanto la figura de Don Alonso como la de El Feri, y tan sangrienta e injustificable aparece la muerte de clérigos a manos de musulmanes como el codicioso saqueo cristiano de los poblados moriscos, siguiendo las fuentes en la creencia, muy extendida en la época, de que los moriscos poseían grandes riquezas (23):

While they were pursuing the flying enemy, the rest of the army, thinking the victory achieved, dispersed themselves over the little plain in search of plunder. They pursued the shrieking females, tearing off their necklaces, bracelets, and anklets of gold; and they found so much treasure of various kinds in this spot, that they threw by their armour and weapons, to load themselves with booty (24).

Sin embargo, el clima más usual tanto entre los héroes propiamente dichos como en el resto de personajes es el de deferencia y generosidad hacia el enemigo, dentro de los usuales tópicos caballerescos. Aqui, o en las Civil Wars de Thomas Rodd, aparecen numerosas muestras de generosidad en ocasiones de enfrentamientos propios de la situación fronteriza. Irving encontró en las fuentes consultadas para su Chronicle... multitud de recreaciones de ejemplos históricos de la generosidad heroica en las guerras granadinas. Con todo, Irving es más parco en describir este rasgo que las fuentes en las que se basa. Amante de la historia fundamentalmente verídica - aunque quizás aderezada con algún detalle pintoresco-, Irving conocía la realidad cruel de las guerras granadinas, y prefiere mencionar el carácter destructivo de los constantes sitios a ciudades y expediciones de forrajeo. Sin embargo, de vez en cuando encontramos algún detalle generoso o noble que nos recuerda las fuentes que utilizó, así como la nueva concepción orientalista que rehabilita al moro. El carácter generoso de la reina Isabel, tan recalcado por las crónicas de la época, es especialmente recreado por Irving. En cuanto a la generosidad y la clemencia en el campo musulmán, el ejemplo más notable es el del moro Zenete, en el sitio de Málaga, que no mata a dos niños que halla en una tienda cristiana, desobedeciendo así las órdenes de no tener piedad con cristiano alguno que les había dirigido un fanático «derviche». Al ser tomada por fin la ciudad:

They were all condemned to slavery, excepting Abrahen Zenete. The instance of clemency which he had shown, in refraining to harm the Spanish striplings on the last sally from Malaga, won him favourable terms. It was cited as a magnanimous act by the Spanish cavaliers; and all admitted, that, though a Moor in blood, he possessed the Christian heart of a Castilian hidalgo (25).

(23) Como ejemplo de ello, el mismo Cervantes pone en boca del morisco Ricote la intención de «sacar el tesoro que dejè enterrado" (vid. Harvey, L.P., «The Moriscos and Don Quijote», University of London, 1974, p. 6) Que los moriscos eran demasiado tacaños, y que por lo tanto llegaban a acumular riquezas que ocultaban era uno entre tantos prejuicios comunes entre los cristianos de la época. Cf. al respecto A. Dominguez Ortiz y B. Vincent, Historia de los Moriscos (1979), ed. Madrid, Alianza, 1984, p. 130, y L. Bernabé Pons, El cántico Islámico del morisco hispanotunecino Taybili, Zaragoza, Institución Fernando el Católico, 1988, p. 37.

(24) W. IRVING: Chronicle..., vol. Il, p. 411.

(25) Ibid, vol. II, pp. 117-118; 133-134. 
Un nuevo ejemplo de la caballerosidad individual - frente a la crueldad global de las guerras - la tenemos en el cap. LXXIX (vol. 2), a la llegada de la reina al campo cristiano:

(...) Some of the troops would have sallied forth in one of their cesperate skirmishes, to attack the royal guard; but the Prince Cidi Yahye forbade them: nor would he allow any artillery to be discharged, or any molestation or insult to be offered: for the character of Isabella was venerated even by the Moors; and most of the commanders possessed that high and chivalrous courtesy, which belongs to heroic spirits; for they were among the noblest and bravest cavaliers of the Moorish nation (26).

Aunque la generosidad no es explicítamente mencionada entre las caracteristicas heroicas de los caballeros ingleses que participaron en la conquista de Granada, para acabar sería interesante citar el párrafo que Agapida (Irving) dedica a la descripción de las tropas del ya mencionado Lord Scales, el más famoso de todos ellos. Entrevemos en ello un tipo de goticismo más suavizado que el de Southey, por ejemplo; se trata de una descripción verdaderamente al modo de las de los héroes renacentistas. Tampoco está exenta de una cierta ironía, observable, por ejemplo, en la dificultad de acomodación de los soldados ingleses, extrapolables a las diferencias de costumbres entre ingleses y españoles que viera Irving en sus viajes a la península:

«This cavalier», he [Agapida] observes, «was from the island of England, and brought with him a train of his vassals; men who had been hardened in certain civil wars which had raged in their country. They were a comely race of men, but too fair and fresh for warriors; not having the sunburnt, martial hue of our old Castilian soldiery; and could not accomodate themselves to the sober diet of our troops, but must fain eat and drink after the manner of their own country. They were often noisy and unruly, also, in their wassail; and their quarter of the camp was prone to be a scene of loud revel and sudden brawl. They were withal of great pride; yet it was not like our inflammable Spanish pride: they stood not much upon the pundonor and high punctilio, and rarely drew the stiletto in their disputes; but their pride was silent and contumelious. Though from a remote and somewhat barbarous island, they yet believed themselves the most perfect men upon earth; and magnified their chieftain, the Lord Scales, beyond the greatest of our grandees. With all this, it must be said of them, that they were marvellous good men in the field, dexterous archers, and powerful with the battleaxe. In their great pride and self will, they always sought to press in the advance, and take the post of danger, trying to outvie our Spanish chivalry. They did not rush forward fiercely, or make a brilliant onset, like the Moorish and Spanish troops, but they went into the fight deliberately, and persisted obstinately, and were slow to find out when they were beaten. Withal, they were much esteemed, yet little liked, by our soldiery, who considered them stanch companions in the field, yet coveted but little fellowship with them in the camps (27).

Considerada como fuente a su vez de otras obras, como ya hemos mencionado antes, tras la publicación en Gran Bretaña y los Estados Unidos de este «king of freak romance with a disconcerting alloy of truth», tal y como lo califica Williams, se aprecia un considerable aumento de ediciones de obras narrativas o dramáticas con el mis-

(?6) ibid., vol. II, pp. 236-7.

(27) Ibid., vol. Il, pp. 329-330. 
mo fondo de las guerras granadinas. Irving fue, por lo tanto, precursor en la literatura de habla inglesa de la última generación «maurófila» romántica al modo de Chateaubriand, y que se prolongará hasta más allá de la mitad de siglo. Concretamente su Chronicle... recogerá por sí sola el entusiasmo que suscitó en otros tiempos la obra de Hita, o ayudará a volverla a poner de moda. The Tourist in Spain, de Thomas Roscoe (1835); Leila or the Siege of Granada, de Bulwer-Lytton (1839); Zaida. A Tale, de Thomas Stuart Trail; «They Key. A Moorish Romance», de Thomas Hood (1844); o la obra ya citada de Felicia Dorothea Hemans, The Abencerrage (1839), que añadimos nosotros, son ejemplos de esta influencia.

A lo largo de estas páginas, hemos podido ojear algunos rasgos aislados de dos de las muchas obras que a lo largo de casi un siglo conformaron un lugar común en la mente inglesa. Un lugar idílico, lejano e irreal, pero que cobró vida en las mentes románticas y halló eco en prácticamente todas las artes europeas y norteamericanas - pero especialmente inglesas - literatura, pintura, arquitectura y música, formando un aspecto importante del mundo romántico que ahora se olvida, en parte por el carácter popular y de poca calidad artística de la mayoría de sus obras. Un mundo que creían real y que contribuían a formar con su aportación, fuera el pequeño romance traducido en un periódico, fuera el relato de sus andanzas por la «Romantick, renown'd land» de España, fuera la grande y esperanzada labor de un Irving o un Thomas Rodd. Aquello fue lo que vieron y sintieron, y asi quisieron dejar el testimonio de su experiencia. 